\title{
Complementary Medicine and Phythotherapy
}

\author{
Tamamlayıcı Tıp ve Fitoterapi
}

(i) Prof. Dr. Adem AKÇAKAYA*

Bezmialem Vakıf University Faculty of Medicine, Head of General Surgery Department, İstanbul, Turkey

\section{Introduction}

Traditional and Complementary Medicine (TCM), which has taken great steps recently in our country, continues to remain on the agenda with many controversial issues. This field, in which applications had been done previously without a scientific base, was discussed within the framework of the Ministry of Health 2013 - 2017 Strategic Plan and Tenth Development Plan of the Republic of Turkey and was reliably and effectively integrated into the health system with an evidence-based approach (1).

TCM is the whole of knowledge, skills and practices based on theories, beliefs and experiences specific to different cultures, used in the prevention of physical and mental illnesses, as well as diagnosis, healing and treatment, as well as protection of health and prevention of diseases (2). They are supportive and complementary methods of today's medicine. Complementary medicine is based on a holistic approach to the patient and disease. The most important sub-unit of complementary medicine is phytotherapy.

\section{What is Phytotherapy?}

Phytotherapy means treatment with herbs. The term was first used by Henri Lenclerc, a French physician and phytotherapist. Human beings have used herbal products since ancient times to treat diseases and have benefited. Phytotherapy products are used for treatment, prevention of diseases or to support other treatments. Often, phytotherapy is used for drug-free life. It is preferred because it is natural, considering that it is harmless. However, every food and food supplement can be a useful drug, as well as a harmful poison for the body.
In our country, the TCM regulation was published in 2014. In this regulation, the purpose, scope and legal basis of TCM are explained very clearly and the characteristics of the practitioners, trainers and the health institutions in which TCM is applied are specified (4). Although this regulation describes many areas, it has not eliminated the abuses made by people who have not received training in this field which is under the counter. The Ministry of Health has banned the application of TCM by persons other than physicians and dentists. The Regulation on the Clinical Researches of TCM Practices that entered into force in 2019 and the TCM Good Clinical Practice Guide prepared based on this determined the research and working conditions in this field (5). However, application of TCM by people from different branches have not received training in herbal products, phytotherapy and TCM could not be prevented.

There are many respected medical doctors dealing with phytotherapy in our country. Particularly, the academicians at the university were interested in this field and the academic studies in this field changed the negative opinions about TCM and the more widespread use of TCM treatments (1). More than 10 centers were given certified training authorization by the Ministry of Health, and more than 30 centers were licensed to practice (5). Unfortunately, specialization in this field has not been achieved in our country, which we think that it should be a branch of education. Although it is widely accepted by the public, some of the academicians, especially from the health community, are still skeptical about this area. Pharmacy faculties' pharmacognosy and phytotherapy departments, agricultural faculties and, medicinal and aromatic plants departments which were recently opened 
at associate degree level increased the interest in this field and endemic vegetation in our country. Promising studies are carried out in the production, research and marketing of medicinal and aromatic plants and these departments are developing rapidly. Dealing with phytotherapy by people who have been educated and are from different branches, even outside the health field, can cause information pollution and wrong practices. When we look at who is interested in phytotherapy in our country, we see the following groups:

1- Those who have participated in the certification program with the trainings given by the Ministry of Health within the framework of TCM trainings and gained the competence to prescribe in this field. This group, which I am a part of, first entered the field of education with the Council of Higher Education approved Phytotherapy center opened at Bezmialem Vakıf University. Later, the TCM training center was opened in many universities and training and research hospitals for physicians and dentists.

2- Those who has become a doctor and completed phytotherapy master and doctorate programs opened by some universities' pharmacy faculties.

3- Pharmacists working in the pharmacognosy and phytotherapy departments of the Faculty of Pharmacy, who have gained experience in this field. Non-physician healthcare professionals holding master's and doctoral degrees in phytotherapy.

4- Those who study biology and chemistry at the faculties of Agriculture and Science and are interested in medicinal and aromatic plants.

5- Graduates of the Department of Medicinal and Aromatic Plants, who are studying at associate degree in some universities.

6- Those who turn to the field of phytotherapy with courses and other trainings after completing their education in a different field.

7- People who has grown up in a family tradition or herbalist shop in this field without any training or who claim to have discovered this area as a result of the illness of themselves or a relative.

As can be seen, only physicians and dentists in the first group of these groups are legal to use phytotherapeutic products in treatment. Any physician can recommend these products, provided that they are trained in this field. However, those who are commonly interested in this field and dominate the market consist of people in the $7^{\text {th }}$ group who have never received any training. Unfortunately, this group has caused loss of trust in TCM applications due to the exploits made in the past. However, the President of the World Health Organization, Dr. As Chan said that abuse would be less in phytotherapy if it was applied by well-trained, experienced and licensed people (6).

As a result, herbal medicines are becoming popular and developing in our country day by day. The loss of reputation in this field due to the abuses committed by people who have not been trained is being regained day by day. The fact that some of our universities such as the Bezmialem Vakıf University, Yıldırım Beyazıt University, Yeditepe University, and Health Sciences University have also turned to this field contributes to the increase of this reputation. Phytotherapy will develop with the contributions of those who believe and trust academicianbased phytotherapy. Phytotherapy will continue to be one of the promising fields of our country in terms of both health and economics by developing the cooperation of medicine, pharmacy, agriculture faculties, medical and aromatic plants departments, and putting their studies into a scientific framework.

${ }^{*}$ Chair of Phytotherapy Association and Trainer of Bezmialem Vakif University, Phytotherapy Training Center.

\section{References}

1. Taştan K . Ülkemizde Geleneksel ve Tamamlayıcı Tıbbın Kilometre Taşları. Ankara Med J. 2018;18:458-459.

2. World Health Organization. General Guidelines for Methodologies on Research and Evaluation of Traditional Medicine. Geneva: WHO Books; 2000:80.

3. https://tr.wikipedia.org/wiki/Fitoterapi, Erişim tarihi:23.03.2021

4. https://www.resmigazete.gov.tr/eskiler/2014/10/20141027-3.htm, Erişim tarihi:23.03.2021

5. https://shgmgetatdb.saglik.gov.tr/TR-56209/geleneksel-vetamamlayici-tip-uygulamalari--klinik-arastirma-dokumanlari.html, Erişim tarihi:25.03.2021

6. http://www.sdplatform.com/Yazilar/Kose-Yazilari/341/Gelenekseltibba-akademik-yaklasim-GETTAM.aspx, Erişim tarihi:23.03.2021 